\title{
慢性副鼻腔炎鼻汁ムチン：その可溶化とOーグルコシド 糖鎖の生化学的研究
}

\author{
東京大学医学部耳鼻咽喉科学教室（主任：野村恭也教授） \\ 杉田公一 \\ MUCIN-TYPE GLYCOPROTEIN OF NASAL SECRETION \\ FROM PATIENTS OF CHRONIC SINUSITIS : \\ SOLUBILIZATION AND BIOCHEMICAL ANALYSIS \\ OF THE O-GLYCOSIDIC OLIGOSACCHARIDE CHAINS
}

KOUICH SUGITA, M.D.

Department of Otolaryngology, Faculty of Medicine, University of Tokyo, Tokyo

Since detailed analysis on the structure and property of mucin in human nasal secretion has not so far performed due to the difficulty of its solubilization, we aimed to investigate the solubilization and the carbohydrate composition of the mucin to clarify the function and the possible involvement by pathological conditions.

Nasal mucopurulent secretions obtained from patients of chronic sinusitis (17 cases, 30ml, dry weight $1650 \mathrm{mg}$ ) were solubilized with $5 \mathrm{mM}$ EDTA-containing phosphate buffered saline (PBS, pH 7.4), and the insoluble materials which were hardly solubilized under the above condition, were solubilized with $8 \mathrm{M}$ urea in PBS. According to the two step solubilization procedures, almost all of the nasal secretions could be solubilized and the recoveries of dry weight, protein, hexose and sialic acid were $92.9 \%, 71.5 \%, 96.4 \%$ and $92.9 \%$, respectively. The soluble fraction with EDTAPBS and the fraction solubilized with urea-PBS (insoluble fraction) were fractionated by Sepharose CL-4B column chromatography and the mucin fractions in the void volume, which contained glycoprotein with the molecular weight of more than $10^{5}$ daltons, were collected. Both mucins retained on a DEAE Sephadex A.25 column, indicating that the majority of the mucins are negatively charged, and their purity and molecular weights were confirmed by SDS-Polyacrylamide Gel Electrophoresis.

In addition, carbohydrate compositions of both soluble and insoluble mucins were determined by gas-liquid chromatography. Molar ratio of carbohydrates in the soluble mucin was Fuc: Man: Gal : GalNAc: GlcNAc: NeuAc $=2.31: 0.13: 4.36: 0.99: 1.81: 1$, and that in the insoluble mucin was Fuc: Man: Gal: GalNAc: GlcNAc: NeuAc $=1.93: 0.33: 5.68: 2.63: 5.44: 1$. The difference between the two mucins with different solubilities was suggested to be mainly due to the aminosugar, which mediate the formation for intra-and inter-molecular linkages to give the viscous nature of the mucin.

Key words : 鼻汁ムチン, 可溶化，ガスクロマトグラフィー, アミノ糖, A89-0715-30140 SDS-PAGE

はじめに

上皮性細胞で合成されるムチンの主な特徴は以下の
ごとくである.(1)分子量が100万ダルトン以上である.

(2)ペプチト鎖含量は30\%以下で残りは糖銷である。(3) 
セリン，スレオニン，プロリンの含量が高い. (4)梼と ペプチド鎖の結合は Oーグリコシド結合による。(5)が ラクトース，Nーアセチルガラクトサミン，N-アセチ ルグルコサミン, フコース, シアル酸, 硫酸を含み, マンノース, ウロン酸,グルコースは含まれない"、ま たムチンはたとえ唯一の腺組織や器官から単離した ものであっても，単一の分子構造を持たず，複数の構 造体の混合物である，一方，ムチンは免疫原性を有す る分子であることが，唾液 ${ }^{2}$ や腸管のムチンについて 調べられており，最近では癌関連糖鎖抗原としての性 質に関心が集まりつつある ${ }^{4) 56)}$. 結局, 分子的定義は明 確ではないが，その性質と役割が重要視されつつある というのがムチン研究の現状といえる。鼻汁ムチンの 構造と機能を調べ臨床への応用を計ることを主眼に研 究を進めているが, 今回は鼻汁ムチンの○ーグリコシド 糖銧に結合している糖の分析を，主としてガスクロマ トグラフィーを用いて行った。舅汁などの粘液の分析 については, 分踓, 精製にさまざまな方法が取られて おり統一されたものはないが，本論文では鼻汁の可溶 化について 5mM EDTA および $8 \mathrm{M}$ 尿素を用い, それ ぞれの方法により可溶化された鼻汁ムチンの相違につ いてがスクロマトグラフィーに上る糖の分析を中心に 進めた。

\section{方法}

\section{1. 試料の鼻汁}

臨床症状，鼻鏡所見，X線検査所見などからら慢性副 鼻腔炎と診断された患者 (13歳〜 42歳)の固有鼻燃より 鼻粘膜を刺激しないように慎重に吸引採取した鼻汁を 用いた，鼻汁の肉眼的性状はすべて粘膿性であった。 採取した鼻汁はディープフリーザー内 $\left(-80^{\circ} \mathrm{C}\right)$ で保存 した。

\section{2. 鼻汁の精製}

試料鼻汁 (14検体，24ml)に5mM EDTA 添加りン酸 緩衝食塩水(PBS, pH7，4)126ml を加之て超音波処理 した。これを $15,000 \mathrm{rpm} て ゙ 30$ 分間遠心後，上清を集め て水に対し透析し，凍結乾燥して得られたものを可溶 性画分とした。一方, 沈渣に $8 \mathrm{M}$ 尿素を加えて, 再び $15,000 \mathrm{rpm} て ゙ 30$ 分間遠心して得られた上清を透析後, 凍結乾燥したものを不溶性画分とした，可溶化前の 試料，可溶性画分および不溶性画分から一部を取り， そのヘキソース含量をフェノール硫酸法で, 蛋白含量 をウシ血清アルブミンを標準蛋白質として FolinLowry法て，シアル酸をレゾルシノール法で定量し
た，つぎに可溶性画分および不溶性画分をそれぞれセ ファロースCL-4Bのカラム $(90 \times 2 \mathrm{~cm})$ でゲルろ過し た。溶出には $6 \mathrm{M}$ 尿素を含むPBS を用いた。溶出液は 試験管ごとに水に対して48時間透析した後，それぞれ についてへキソース含量をフェノール硫酸法で, 蛋白 質含量をUV吸収 $(280 \mathrm{~nm})$ で定量した。この中の pass -through fraction で特に糖含量の高い画分を可溶性 画分では可溶性ムチン画分(s-I)，不溶性画分では不溶 性ムチン画分（i-I）とした。また，2番目のピークの うち特に糖含量の多い画分を可溶性画分では s-II，不 溶性画分では i-II とした。

3. ガスクロマトグラフィーによる糖の定量

2.で得た各試験管から $50 \mu 1$ ずつ採取して,これを 凍結乾燥後, メタノリック塩酸 $400 \mu 1$ 抢よび眽酸メチ ル $100 \mu 1$ を加えて混合し， $70^{\circ} \mathrm{C} て ゙ 16$ 時間反応させた。 これに内部摽準物質としてマンニトール $25 \mu \mathrm{g}$ を水 $100 \mu 1$ に溶解した液を加えて室温で窒素ガスにより乾 燥させた。さらにメチルアルコール $500 \mu 1$, ピリジン $50 \mu 1$, 無水酷酸 $50 \mu \mathrm{l}$ を加えて室温で15分間放置後, 窒 素ガスで溶媒を除いた後, デシケーター内で乾燥させ た。これにへキサン $100 \mu 1$ を加えたものをがスクロマ トグラフィー用の試料とした。

使用したガスクロマトグラフは島津製作所製 GC$7 \mathrm{AG}$ または GC-9Aである。カラムは $1 \% \mathrm{OV}-101$ お よび $3 \% \mathrm{SE}-30$ を用いた. 分析条件は初期温度 $160^{\circ} \mathrm{C}$ から最終温度 $250^{\circ} \mathrm{C}$ まで $2{ }^{\circ} \mathrm{C} /$ 分で昇温させた。 あら かじめ, 既知量の糖とマンニトールで検量線を求めて おきこれより各試料中の栯含量を定量した。精のう ちシアル酸についてはレゾルシノール法で定量した.

4. SDS-ポリアタリルアミドゲル電気泳動 (SDSPAGE) による分析

2.で得た各試験管から $100 \mu 1$ ずつ採取して，これに $1 \%$ ドデシル硫酸ナトリウム (SDS) 添加 $20 \%$ ショ 楉を $100 \mu 1$ およびマーカー色素ブロムフェノール・ブ ルー(BPB 1\%) $50 \mu 1$ を加えて $40^{\circ} \mathrm{C} て ゙ 2$ 時間放置した。 これをSDS-PAGE 用の試料とした。 $7 \%$ アクリルア ミドゲルを用いて $80 \mathrm{~V} ， 60 \mathrm{mAC゙} 4$ 〜時間泳動した。 標準物質としてはチトクロームC（分子量11,700），ミ オグロピン（分子量17,000), カルボニック・アンハイ ドラーゼ (分子量 31,000 ), 卵白アルブミン（分子量 43.000), ウシ血清アルプミン（分子量68,000）を用い た.

5. DEAEセファデックス A-25クロマトグラフィ 一による分析 in 
$\mathrm{s}-1$ および $\mathrm{i}-1$ をDEAEセファデックス A-25カラ 么 (容積 $90 \mathrm{ml}$ )で分画した. $10 \mathrm{mM}$ トリス塩酸緩衝液 を用いて0から $1.6 \mathrm{M} の \mathrm{NaCl}$ の濃度勾配をつけて溶 出した。溶出パターンは, 糖(フェノール硫酸法) お よU゙蛋白質（UV 吸収，280nm）でモニターした。

\section{1. 鼻计の精製}

鼻汁の精製に用いた鼻汁混合液 $24 \mathrm{ml}$ の乾燥重量は

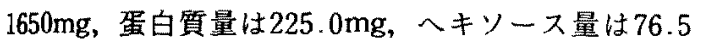
$\mathrm{mg}$ 、シアル酸量は $32.4 \mathrm{mg}$ であった。また可溶性画 分の乾燥重量は $1284 \mathrm{mg}$, 蛋白質量は $143.9 \mathrm{mg}$, 人キ

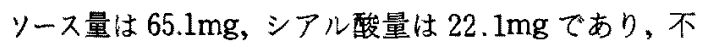
溶性画分の乾燥重量は $240 \mathrm{mg}$, 蛋白質量は $16.9 \mathrm{mg}$, 入

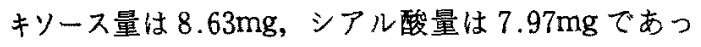
た.これらの関係を図 1 に示す。この中で可溶性画分 と不溶性画分の合計加回収量を計算すると初めの混 合没に対して, 乾燥重量で $92.9 \%$, 蛋白質量で $71.5 \%$, ヘキソース量で $96.4 \%$ ，シアル酸量て $92.9 \%$ ありり,
ほとんどの構成成分，特に糖は二つの画分に可溶化さ れていることがわかった，可溶性画分と不溶性画分と の割合は乾燥重量で $77.8 \% と 14.5 \%$, 蛋白質量で $64.0 \%$ と $7.5 \%$ ，ヘキソース量で $85.1 \%$ と $11.3 \%$ ，シ アル酸量で $68.3 \%$ と $24.6 \%$ であっ.したがって，こ の值をもとに不溶性画分への分配率を求めると, 乾燥 重量で $15.7 \%$ ，蛋白質量で $10.5 \%$ ，ヘキソース量で $11.7 \%$, シアル酸で $26.5 \%$ となりシアル酸の不溶性画 分への分布は比較的高い值であった。

可溶性画分拈上び不溶性画分のセファロース CL-4 Bでの溶出のパターンを図 2 に示す。いずれの画分に おいてもCL-4B では 2 個の主ピークを与え，そのう ち特に梼含量の多い画分を可溶性画分ではs-I（可 溶性ムチン画分)，s-II とし，不溶性画分ではi-I (不 溶性ムチン画分)，iＩI とした。

2. 糖の定量

試験管ごとに定量した糖のモル数を合計してその中

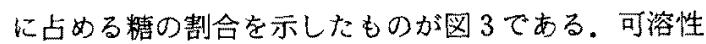
画分の中で比較すると各試験管での糖の割合は比較的

\section{Mucopurulent nasal secretions (14 samples) dry weight $1650 \mathrm{mg}$.}

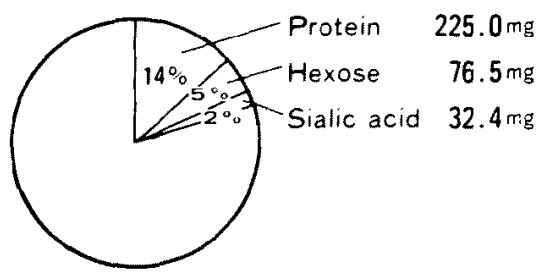

Dry weight

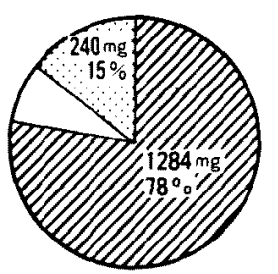

Protein

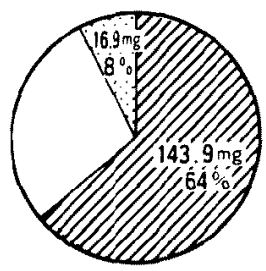

Hexose

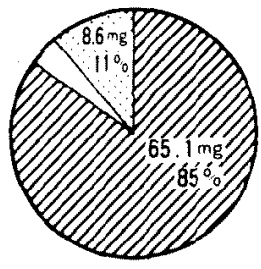

Sialic acid

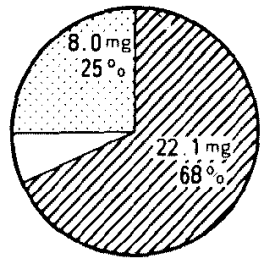

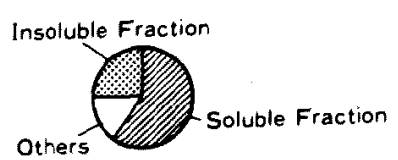

Protein : Lowry method

Hexose : Phenol-Sulfuric acid method

Sialic acid: Resorcinol $\mathrm{HCl}$ method

图 1 可溶性画分および不溶性画分の化学組成 
一定しているが, 血清蛋白由来成分に多いとされてい るマンノースは S-IIで増加している. 可溶性ムチン画 分 (s-I) における糖の重量は溶出液 $1 \mathrm{ml}$ あたりフコ ース $257.0 \mu \mathrm{g}$ ，マンノース $15.9 \mu \mathrm{g}$ ，ガラクトース $550.2 \mu \mathrm{g} ， \mathrm{~N}$ ーアセチルガラクトサミン $153.6 \mu \mathrm{g}, \mathrm{N}-$
アセチルグルコサミン $281.3 \mu \mathrm{g}$, シアル酸 $215.5 \mu \mathrm{g} て ゙$ あった，これをシアル酸の值を 1 として糖のモル比を 求めると抢よそフコース: マンノース：ガラクトー ス：Nーアセチルガラクトサミン：Nーアセチルグルコ サミン: シアル酸 $=2.31: 0.13: 4.36: 0.99: 1.81$ :

\section{Elution Profile of Sepharose CL-4B Soluble Fraction}

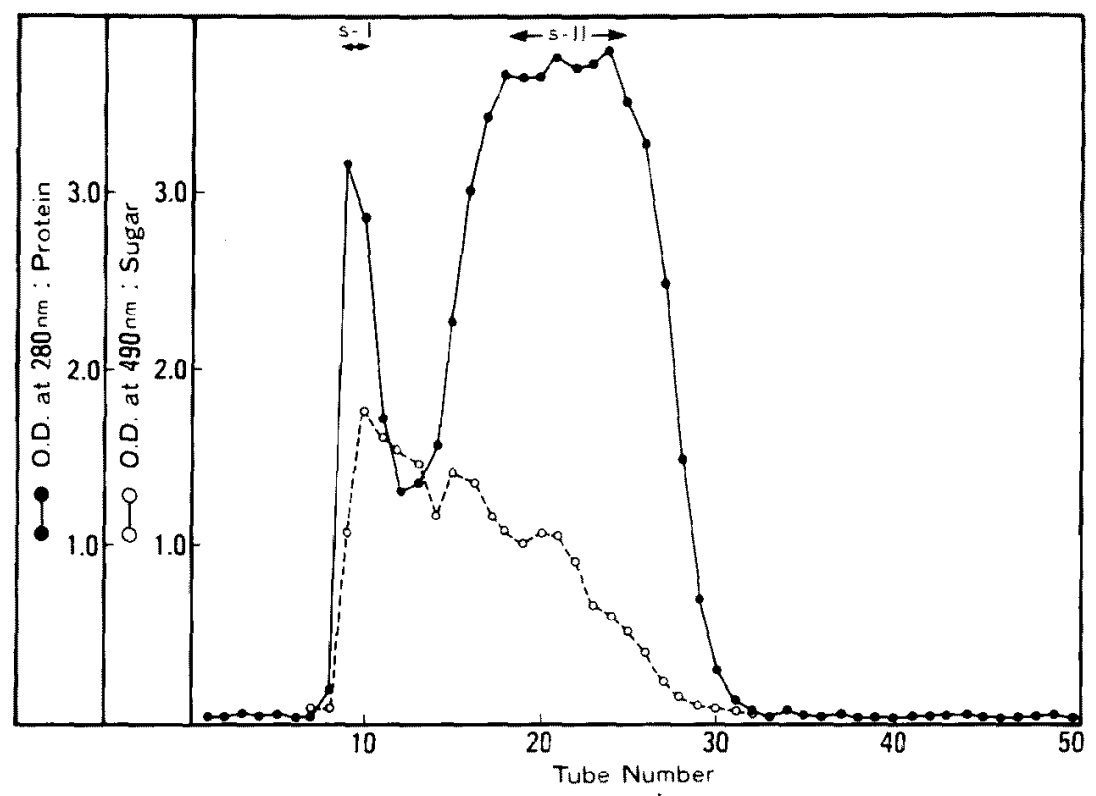

Elution Profile of Sepharose CL-4B Insoluble Fraction

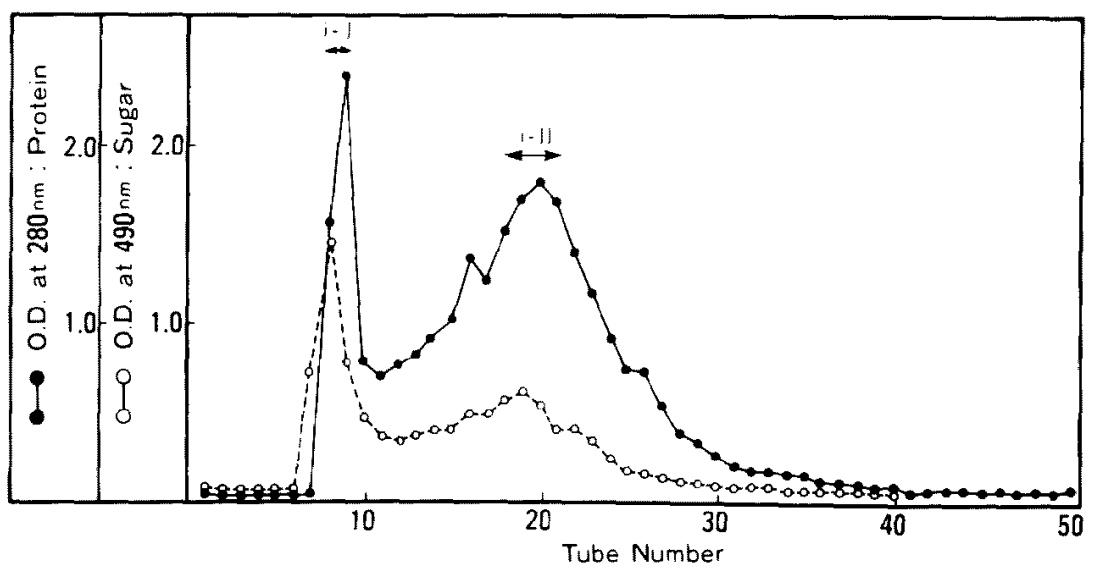

図 2 可溶性画分および不溶性画分の CL-4Bでの溶出パターン

上段：可溶性画分，下段：不溶性画分

S-I：可溶性ムチン画分，i－I：不溶性ムチン画分 

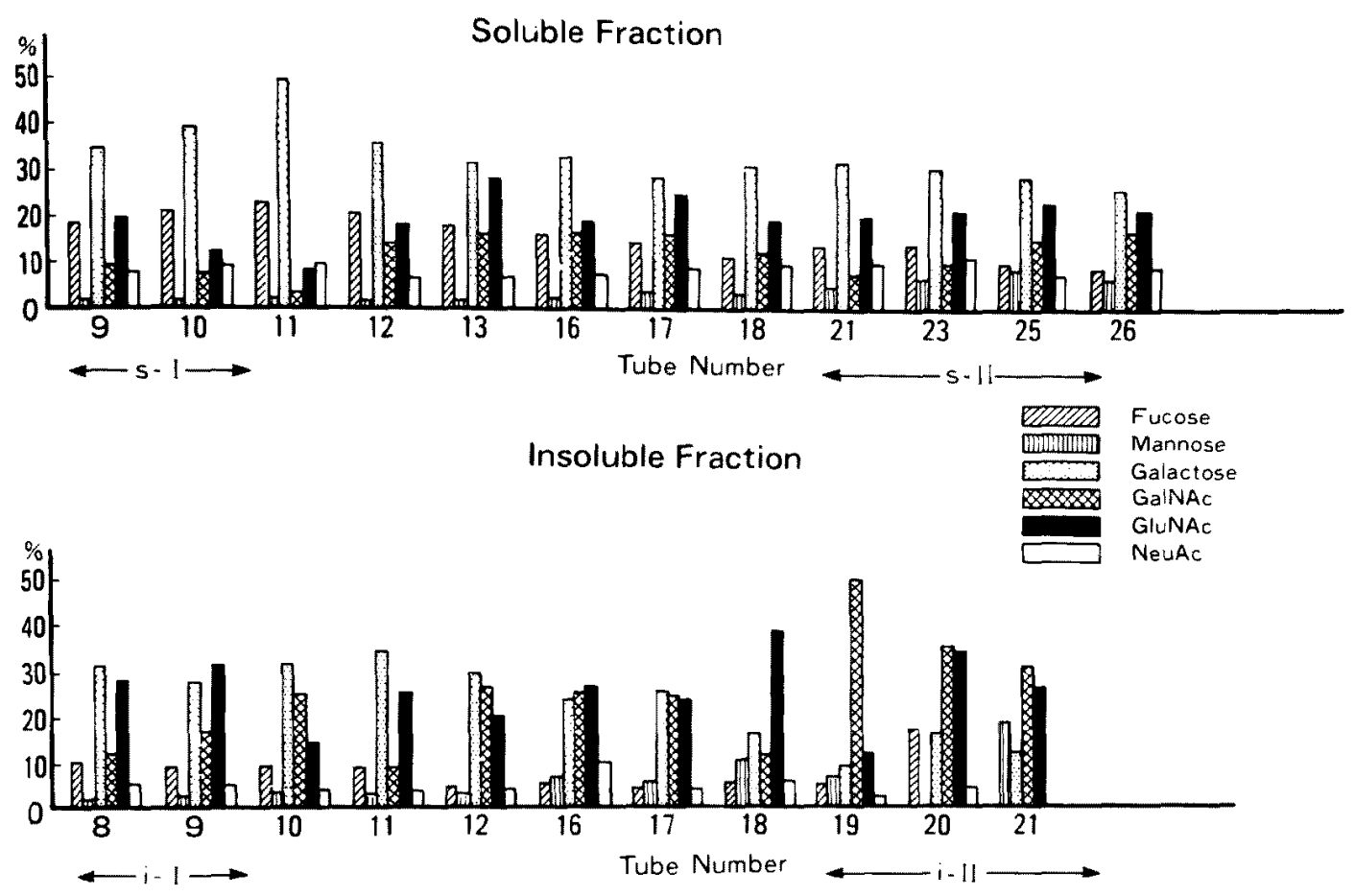

图 3 試験管ごとの糖のモル数の百分率 上段：可溶性画分，下段：不溶性画分

S-I：可溶性ムチン画分，i－I：不溶性ムチン画分

1となった，不溶性画分では可溶性画分に比較してい ずれの試験管も糖の割合に変化が大きいこと，ガラク トースははじめのムチン画分に多く，後になるほど減 少すること, マンノースは逆に後になると增加するこ とが示された。不溶性ムチン画分 (i一Ｉ）での糖の重量 は溶出液 $1 \mathrm{ml}$ あたりフコース $17.9 \mu \mathrm{g}$, マンノース

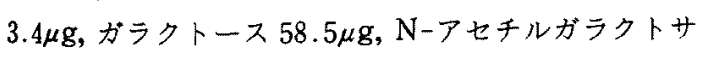

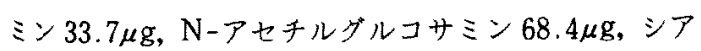
ル酸 $17.8 \mu \mathrm{g}$ であった。これを同様にシアル酸の值を 1として糖のモル比を求めるとフコース: マンノー ス:ガラクトース: N-アセチルガラクトサミン: Nアセチルグルコサミン: シアル酸=1.93:0.33: $5.68: 2.63: 5.44: 1$ となった.

3. SDS-ポリアクリルアミドゲル電気泳動による 鼻汁の分析

可溶性画分および不溶性画分を同一条件で電気泳動 し，それそれについて蛋白質の染色としてクマッシー フリリアントブルー染色を，また糖の染色として PAS 染色を行った（図 4)、S-I 招よびi-Iのいずれも蛋白質
は泳動されておらず，基線の位置のみが強く染色され ている.この基線の位置は分子量100万ダルトン以上と 推定される、S-II 抢よび i-IIではいずれも複数のバン ドが染色されて扔り整準蛋白質から分子量を推定して アルブミン（分子量68,000），トランスフェリン（分 子量75,000) などが考えられた。一方，糖について見 ると s-I，i-Iの基線の位置がやはり強く染色されてい て，これが糖の豊富な画分でることが示された。

4. DEAEセファデックス A-25によるクロマトグ ラフィー

可溶性ムチン画分を陰イオン交換樹脂で分離する と, $\mathrm{NaCl}$ の濃度で $0.36 \mathrm{M}, 0.61 \mathrm{M}$ に 2 本のピータが得 られた，非吸着成分はなく，ほとんどが吸着される。

これはシアル酸もしくは硫酸を含む成分が相互分離し ているためと予想される，不溶性ムチンも同様に非吸 着成分はほとんど含まれず，ほほすべての成分がカラ ムに吸着された。その溶出位置は $0.50 \mathrm{M} \mathrm{NaCl} 1$ 本 のピークとして観察された。 

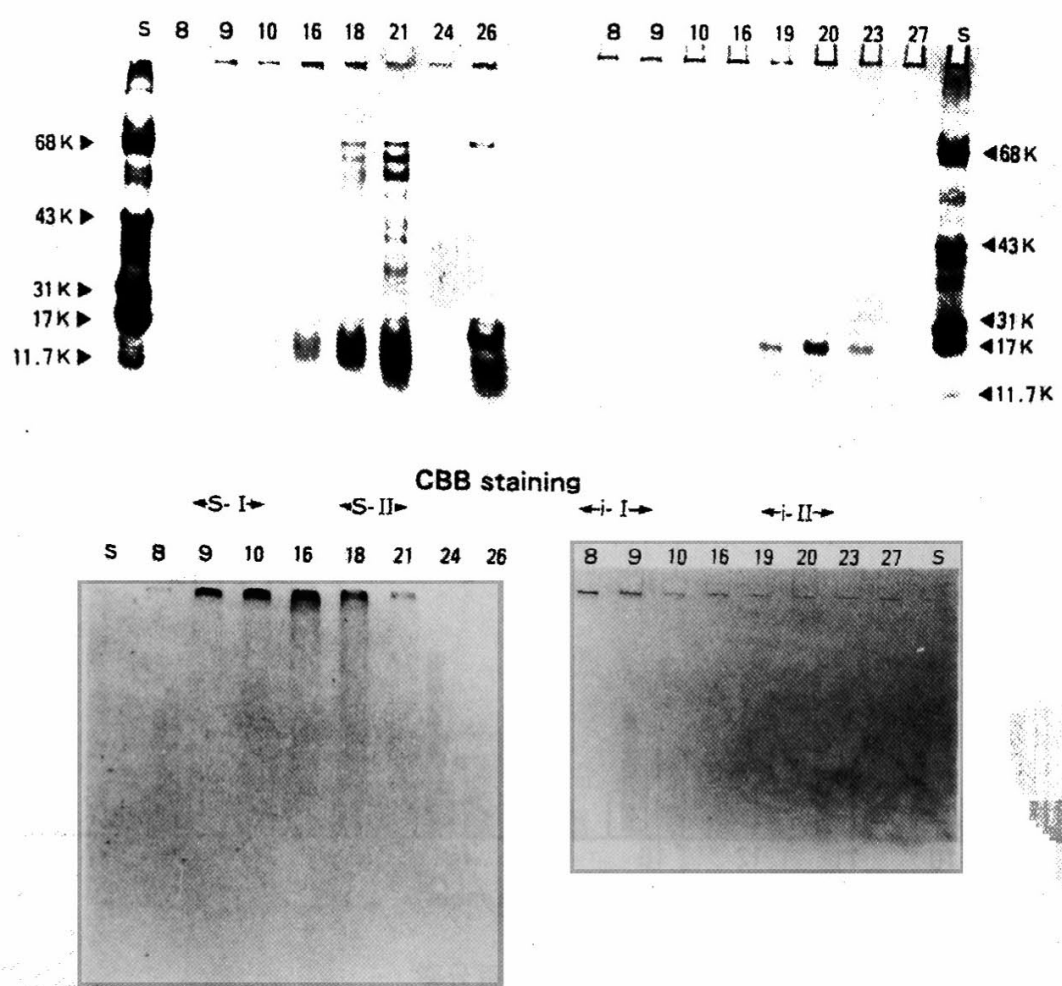

Soluble Fraction PAS staining

Insoluble Fraction

図 4 SDS-ポリアクリルアミドゲル電気泳動

上段：クマシーブリリアントブルー染色, 下段はPAS 染色 左側：可溶性画分，右側：不溶性画分

s - I ：可溶性ムチン画分, i - I ：不溶性ムチン画分

\section{考案}

気道, 消化管, 生殖器などに扔ける分泌物の主成分 であるムチンの一般的な役割には，器官内での潤滑作 用, 食物を包み込み粘膜を傷つけずに混和, 消化して 腸へ送る庇護作用, 胃の防御因子としての作用, 外来 物の排出に際しての作用, 子宮腔の保護, 精子の生存 と貫通性の調節などがある。最近特に注目されている のはムチン糖鎖構造の癌化時の変化であり, 消化管么 チンの抗原性の癌性変化は良〈知られている ${ }^{4) ~ 77 . ~ 一 ~}$ 方, ムチンの構造は徐々に解明されつつあり, 消化管, 顎下腺, 気管のムチンの構造についての報告が見られ $3^{8) 99}$. ムチンの分子構造の模式図を図 5 に示した、ム チン分子はポリペプタイドからなるコアに糖の側鎖が セリンもしくはスレオニンを介してOーグリコシド結 合している ${ }^{10}$. また, ムチン分子間や自らの分子内でジ スルフィド結合や二価の陽イオンなどを介したイオン
結合が形成され，その粘性に関与している，ムチンの 構造と機能を検索する方法は, ムチン分子自体の分子 構造的定義が確立されておらず，精製の指標となるも のがないため, O-グリコシド結合を開裂して単離した 糖鎖の構造を解析するか, あるいは免疫学的手法を用

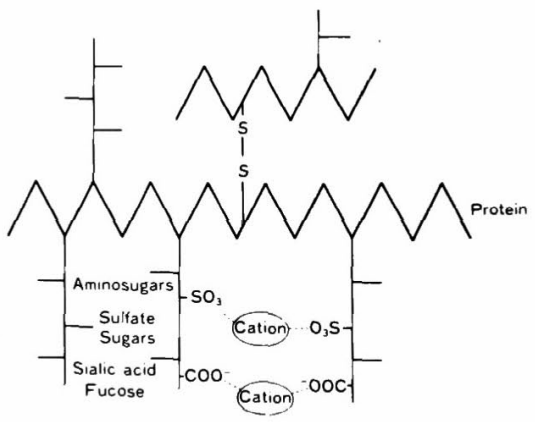

図 5 酸性ムチン分子の模式図 
いて抗原の産生細胞を組織化学的に調ベる方法がもっ ぱら用いられてきだ”. 著者らは，慢性副鼻腔炎患者の 粘膿性鼻汁を精製して得た可溶性ムチンを家兔に免疫 することにより，抗鼻汁ムチン抗血清を作製し，その 抗血清の性䁈や抗血清によって認織される抗原構造を 解析することによって,ムチンの○ーグリコシド糖鎖が その発現に大きく関与していることを明らかにし，ま た抗血清を用いた蛍光抗体法により上影洞粘膜におけ るムチン分布の所見について報告した ${ }^{122}$. 今回の報告 は鼻汁ムチンについての研究の一環として，鼻汁ムチ ンの可溶化とのーグリコシド梼鎖についての生化学的 分析を試み，その結果から，ムチンの物理的性質を付与 する化学的棈造の背景について考察を加えたものであ る.

ヒト鼻汁ムチンについての研究は, 最近では大山衫, 坂食 ${ }^{14)}$, Patow ら ${ }^{15)}$, Boat ら ${ }^{16)}$ の報告があるがいまだ 不明な点が少なくない．上卜鼻汁么チンの研究上の問 題の一つに，正常鼻汁を分析に十分な量を採取するこ とが困難なことがあげられる，そもをも鼻汁は正常な 状態では鼻粘膜上に二層の mucous blanket として存 在し(1), その厚さは約 $5 \mu \mathrm{m}$ とされている ${ }^{14)}$. 正常者か ら採取する方法として,生理食塩水で鼻腔内を洗浄し， その洗浄液を採取したり，綿球またはろ紙を鼻腔内に

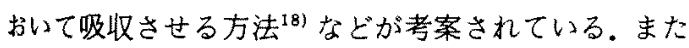
鼻汁を誘発させる方法も低温室で温かい麵類を食べる 方法 ${ }^{19)}$ や各種薬版を吸入させる方法などがある。いず れの方法でも「正常鼻汁」とは言いがたく，また量的 にも十分ではない，また，最近行われている粘膜の組 誡培養による結果をそのままヒトに当てはめることは てきない ${ }^{15) 16200}$. 一方, 慢性副鼻腔炎は主要鼻疾患の一 つであるが，その主病態は鼻，副鼻腔粘膜上皮の杯細 胞，腺細胞および血管からの気道粘液の過剩分泌に上 る鼻漏過多である。その分泌液は肉眼分類で阽性, 粘 償性、膿性に分けられるが，比較的軽症例では粘性が 多く，一般的には粘膿性が多い，慢性副鼻腔炎患者の 鼻㚈の場合は個体差や病期による相違は存在するが， 绫発せずに固有鼻腔内の貯留液を被検者に大きな負担 をかけずにある程度の量を採取できる利点がある。し たがって, 本研究では慢性副鼻腔炎患者から採取した 舅计を分析に用いた。

鼻斗の分析において，単に遠心すると“gel phase”と よばれる粘液糖蛋白の豊富な画分と“sol phase”と よ代れる少量の粘液精蛋白, 血清蛋白, 分泌蛋白, 小 分子量の物質の含まれる画分とに分けられる，前者の
粘液精蛋白(ムチン)は不溶性で後者と自由に混合させ ることはできない，そこでムチンの可溶化が必要とな る、この方法としては1）蛋白分解䣲素たとえばパパ イン, プロナーゼなどを用いて, 分子量 $3 \sim 6 \times 10^{5}$ ダ ルトンの断片にする，2）チオール複合体すなわち $\mathrm{N}$ ーアセチルシステイン,ジチオスレイトールなどでジス ルフィド結合を開裂する３）水素結合開裂剤たとえ ば疗素, グアニジン塩,アセトアミドを用いる，4）超 音波処理などがある ${ }^{21 !}$. 本研究ではカルシウムなどの 陽イオンのキレート率であるEDTA と蛋白変性剂で 水素結合を切断する尿素を用いた，EDTAによって 可溶化される画分を可溶性画分とし，そのなかでも糖 含量の多い画分を可溶性ムチン画分とした。 また尿素 によって可溶化される画分を不溶性画分とし，そのな かで特に糖含量の多い画分を不溶性ムチン画分とし た。この両者の方法を組み合わせるとチオールなどで ジスルフィド結合を開裂しなくてもへキソース量で $96.4 \%$ とほとんどの糖が可溶化され，ムチンの可溶化 には極めて有効な方法であることがわかった。

これまで気道分泌液の糖成分の定量的研究は多数あ るが，鼻汁中にはさまざまな構成成分が含まれること を考えると定量した糖の由来を明確にする必要があ り，本研究ではゲルろ過で分画した試験管ごとに糖を 分析し，さらにその溶出液の分子量を確認するために SDS-ポリアクリルアミドダル電気泳動を行った。その 結果, 可溶性ムチン画分扔よび不溶性ムチン画分は分

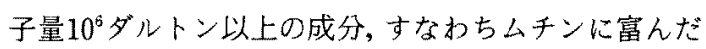
画分であることが示された。

番汁ムチンの○ーグリコシド結合糖鎖に含まれてい るとされる糖はフコース,ガラクトース, N-ア七チル ガラクトサミン，Nーアセチルグルコサミン，シアル 酸年である. Clark ら ${ }^{221}$ はラットの気管の移植片から のムチンをセファロース CL-6B およびセファロース $\mathrm{CL}-4 \mathrm{~B}$ でゲルろ過しその溶出パターンで画分を3つ に分けて分析している．その中の初めのピークは本研 究の可溶性ムチン画分に相当すると思われるが，そこ での糖のモル比をシアル酸を1として求めるとフコー ス0.33, マンノース0.33, ガラクトース $3.31, \mathrm{~N}-ア セ$ チルガラクトサミン $2.13, \mathrm{~N}-$ アセチルグルコサミン 2.90となる，上卜気道では下気道ムチンについての報 告が中心であるが ${ }^{23)}$, 鼻科領域では, 培責した甲介粘膜 からのムチンを分析した研究があり，糖のモル比はフ コース0.79, ガラクトース2.29, ヘキソサミン 2.63 , シアル酸 1 と報告されている ${ }^{15)}$. 本研究でのモル比は 
可溶性ムチン画分でフコース2.31, マンノース0.13, ガラクトース4.36, N-アセチルガラクトサミン0.99,

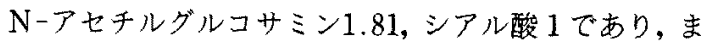
た一方，不溶性ムチン画分ではフコース1.93，マンノ ース0.33,ガラクトース $5.68, \mathrm{~N}-$ アセチルガラクトサ ミン2.63, N-アセチルグルコサミン 5.44 , シアル酸 1 であった。報告者間の相違は鼻汁の採取方法，ムチン の精製法，炎症の有無などに起因すると考えられる。 可溶性ム千ン画分と不溶性ムチン画分の相違は可溶化 の違いから水素結合の架橋度に上るものと考えられる が，それらを構成する糖組成の上からは不溶性ムチン 画分にはN-アセチルガラクトサミンとNーアセチルグ ルコサミンなどのアミノ糖が多い.したがって，アミ ノ基がムチン分子の物理学的性質に関与している可能 性が考えられる。

\section{まとめ}

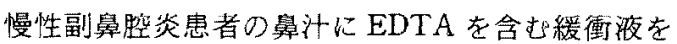
加え超音波処理で可溶化した，鼻汁中にはこの操作に よっても全く可溶化されない成分が含まれるが，この 成分は尿素による処理でほぼ完全に可溶化された。こ れは添加尿素による水素結合開裂によるものと考えら れる。それぞれを可溶性ムチン画分, 不溶性ムチン画 分としたが，両者とも酸性の性質を示し中性ムキンは ほとんど含まれていなかった，両ムチン画分の糖成分 を分析し，構成糖のモル比を比較すると，アミノ桾含 量が不溶性ムチン画分に高くなった。したがって，可 溶化の際の性筫の相違はアミノ糖含量すなわちアミノ 糖を介した分子内あるいは分子間の架憍度の相違によ ることが予想された。

\section{参考文 献}

1) Forstner JF: Intestinal mucins in health and disease. Digestion 17: 234-263, 1978.

2) Oemrawsingh 1, Roukema PA: Immunological characterization and detection of human subman. dibular mucins in saliva dental plaque and submandibular glands. Arch Oral Biol 21 : 755-759, 1976.

3) Jabbal I, Kells DIC, Forstner G et al : Human intestinal goblet cell mucin. Can J Biochem 54: 707$716,1976$.

4) Filipe MI, Branfoot AC: Abnormal patterns of mucus secretion in apparently normal mucosa of large intestine with carcinoma. Cancer $34: 282-$ 290,1974
5) Gold DV, Miller F : Comparison of human colonic mucoprotein antigen from normal and neoplastic mucosa. Cancer Research 38: 3204-3211, 1978.

6) Kurosaka A, Nakajima $H$, Funakoshi $I$ et al: Structures of the major oligosaccharides from a human rectal adenocarcinoma glycoprotein. J Biol Chem 258: 11594-11598, 1983.

7) Nakajima H, Kurosaka A, Fujisawa $A$ et al: Isolation and characterization of a glycoprotein from a human rectal adenocarcinoma. J Biochem $93: 651$ $-659,1983$.

8) Gerken TA, Dearborn DG: Carbon-13 NMR studies of native and modified ovine submaxillary mucin. Biochemistry 23 : 1485-1497, 1984.

9) Lamblin G, Boersma A, Lhermitte $M$, et al : Further characterization, by a combined high-performance liquid chromatography/ ${ }^{1} \mathrm{H}-\mathrm{NMR}$ approach, of the heterogeneiety displayed by the neutral carbohydrate chains of human bronchial mucins. Eur J Biochem 143: 227-236, 1984.

10) Clamp $J$ : Mucus in health and disease. in Parke DV, Elstein M (ed) : Mucus in health and disease. Planum Press, New York, 1977, pp. 1-15.

11) Fleming $N$, Brent $M$, Arellano $R$ et al: Purification and immunofluorescent Iocalization of rat submandibular mucin. Biochem J 205 : 225-233, 1982.

12）杉田公一，洲崎春海他：ヒト鼻汁および精製ムチン に対する抗血清の作製と免疫組織化学への応用に関吉 る研究. 日耳鼻 88：1032-1039，1985.

13）大山 勝：上気道粘膜の病態生化学. 鹿児島大学耳鼻 咽喉科学教室, 1984 .

14）坂倉康夫：上卜鼻腔粘液線毛機能, 態沢忠躬, 野村萑也 編：鼻科学臨床所見の定量化. 金原出版, 東京, 1985, 78-124面.

15) Patow CA, Shelhamer J, Marom $Z$, et al: Analysis of human nasal mucous glycoproteins. Am J Otolaryngol $5: 334-343,1984$,

16) Boat TF, Kleinerman JI, Carlson DM et al: Human respiratory tract secretions. Am Review Respira. tory Disease 110: 428 -441, 1974.

17) Lucas AM and Douglas LC: Principles underlying cillary activity in the respiratory tract. Arch Otolar. yngol $20: 518-541,1934$.

18) Munich HE: Present possibilities for diagnosis in human nasal secretions. Rhinology 21 : 223-228, 1983.

19) Sakakura Y, Majỉma Y, Yoshii S et al : Nasal

(1) 
secretion from normal subjects. Auris Nasus Larynx 6:71-78, 1979.

20) Boat TF and Cheng PW: Biochemistry of airway mucus secretions. Federation proc 39: 3067-3974, 1980.

21) Widdicombe JG and Weiis UM: Chapt. 9 Airway secretion in Proctor DF and Andersen IB (ed) : The Nose. elsevier biomedical, Amsterdam, 1982, pp. 215-244.

22) Clark $J \mathrm{~N}$ and Marchok $\mathrm{AC}$ : Characterization of mucin isolated from rat tracheal transplants. Biochim et Biophysica Acta 588: 357-367, 1979.

23) Woodward H, Horsey B, Bhavanbandan VP et al : Isolation, purification, and properties of respiratory mucus glycoproteins. Biochemistry 21: 694-701,
1982.

稿を終わるに臨み, 御指導, 御校閲を賜わった恩師野村恭 也教授に深甚なる感謝の意を捧げる。また，終始暖かい御指 脜を戴いた洲崎春海博士に深く感謝する。本研究は主とし て本学第二生化学教室で行われたものであるが, 研究の場 を提供され，直接の御指導を戴いた永井克孝教授，岩森正男 博士に衰心より感謝する。

本論文の要旨は第86回日本耳鼻咽喉科学会総会において 報告した。

（原稿受付 昭和60.10.11日）

別刷請求先 $=113$ 東京都文京区本鄉7-3-1 東京大学医学部耳鼻咽喉科学教室 杉田公- 